\title{
Sintesis dan Karakterisasi Lempung Magnetik (Mg/Al-Fe Hydrotalcite) serta Aplikasinya Sebagai Adsorben Asam Fulvat
}

\author{
Irwan Agung Saputro ${ }^{1}$, Karmanto ${ }^{2}$ \\ ${ }^{1}$ Researcher of QA, PT De Glow International \\ ${ }^{2}$ Kimia, Fakultas Sains dan Teknologi, Universitas Islam Negeri Sunan Kalijaga \\ irwanagungsaputro@gmail.com
}

\begin{abstract}
ABSTRAK
Sintesis lempung magnetik ( $M g / A l-F e$ Hydrotalcite) serta aplikasinya sebagai adsorben asam fulvat telah dilakukan. $\mathrm{Mg} / \mathrm{Al}-\mathrm{Fe}$ Hydrotalcite disintesis dengan cara mereaksikan larutan $\mathrm{FeCl}_{2} .6 \mathrm{H}_{2} \mathrm{O}$ dan $\mathrm{FeSO}_{4} .7 \mathrm{H}_{2} \mathrm{O}$ (1:1) dengan $\mathrm{Mg}\left(\mathrm{NO}_{3}\right)_{2} .6 \mathrm{H}_{2} \mathrm{O}$ dan $\mathrm{Al}\left(\mathrm{NO}_{3}\right)_{3} .9 \mathrm{H}_{2} \mathrm{O}$ (2:1) menggunakan metode kopresipitasi serempak pada interval $\mathrm{pH}$ 10-13. Kajian sintesis meliputi kajian karakteristik padatan hasil sintesis menggunakan difraktometer sinar-X dan spektrometer FTIR, uji kemagnetan $\mathrm{Mg} / \mathrm{Al}$-Fe Hydrotalcite menggunakan medan magnet luar serta uji kestabilan $\mathrm{Mg} / \mathrm{Al}$-Fe Hydrotalcite dalam berbagai $\mathrm{pH}$ medium. Asam fulvat diisolasi menggunakan larutan metanol dan dikarakterisasi menggunakan spektroskopi FTIR. Kajian adsorpsi dan desorsi asam fulvat dipelajari dengan mengkaji kinetika adsorpsi asam fulvat oleh $\mathrm{Mg} / \mathrm{Al}-\mathrm{Fe}$ Hydrotalcite serta pengaruh waktu terhadap konsentrasi asam fulvat terdesorpsi dari $\mathrm{Mg} / \mathrm{Al}-\mathrm{Fe}$ Hydrotalcite. Hasil karakterisasi menunjukkan karakteristik puncak serta gugus fungsi $\mathrm{Mg} / \mathrm{Al}-\mathrm{Fe}$ Hydrotalcite dalam difraktogram sinar-X dan spektra FTIR. Kestabilan Mg/Al-Fe Hydrotalcite cenderung stabil pada $\mathrm{pH}$ di atas 3. Berdasarkan data spektra FTIR, asam fulvat Teluk Panji memiliki gugus fungsi utama yaitu - $\mathrm{COOH}$ (alifatik dan aromatik) dan gugus - $\mathrm{OH}$ fenolat. Hasil pola adsorpsi asam fuvat oleh $\mathrm{Mg} / \mathrm{Al}$-Fe Hydrotalcite merupakan kinetika reaksi orde satu yang mencapai kesetimbangan dengan konstanta laju reaksi $\left(\mathrm{k}_{1}\right)$ sebesar $24 \mathrm{x}^{-4} 0^{-4}$ menit $^{-1}$. Hasil karakterisasi pasca adsorpsi menunjukkan bahwa asam fulvat masuk ke dalam antar lapis $\mathrm{Mg} / \mathrm{Al}$-Fe Hydrotalcite yang dibuktikan dengan peningkatan harga basal spacing pada $\mathrm{d}_{003}$ yang merupakan karakteristik dari hydrotalcite. Pengaruh waktu terhadap konsentrasi asam fulvat terdesorpsi menunjukkan asam fulvat mampu terdesorpsi dari $\mathrm{Mg} / \mathrm{AlFe}$ Hydrotalcite sebesar 82,83\% atau sebesar 18,52 $\mathrm{mg} / \mathrm{L}$ dari konsentrasi total 22,3556 mg/L. Kata kunci: Mg/Al-Fe Hydrotalcite, adsorpsi, desorpsi, asam fulvat.
\end{abstract}

Kata kunci: adsorpsi; desorpsi; asam fulvat; $\mathrm{Mg} / \mathrm{Al}-\mathrm{Fe}$ Hydrotalcite.

\begin{abstract}
Synthesis of magnetic clay ( $\mathrm{Mg} / \mathrm{Al}-\mathrm{Fe}$ Hydrotalcite) and its application as fulvic acid adsorbent has been carried out. $\mathrm{Mg} / \mathrm{Al}-\mathrm{Fe}$ Hydrotalcite was synthesized by reacting $\mathrm{FeCl}_{2} .6 \mathrm{H}_{2} \mathrm{O}$ and $\mathrm{FeSO}_{4} .7 \mathrm{H}_{2} \mathrm{O}$ (1: 1) solutions with $\mathrm{Mg}\left(\mathrm{NO}_{3}\right)_{2} .6 \mathrm{H}_{2} \mathrm{O}$ and $\mathrm{Al}\left(\mathrm{NO}_{3}\right)_{3} .9 \mathrm{H}_{2} \mathrm{O}(2$ : 1) using the coprecipitation method simultaneously at $\mathrm{pH}$ intervals 10-13. Synthesis studies include the study of the characteristics of solids synthesized using X-ray diffractometer and FTIR spectrometers, $\mathrm{Mg}$ / Al-Fe Hydrotalcite magnetism test using an external magnetic field and $\mathrm{Mg} / \mathrm{Al}-\mathrm{Fe}$ Hydrotalcite stability test in various medium $\mathrm{pH}$. Fulvic acid was isolated using methanol solution and characterized using FTIR spectroscopy. The study of fulvic acid adsorption and desortion was studied by studying the fulvic acid adsorption kinetics by $\mathrm{Mg} /$ $\mathrm{Al}-\mathrm{Fe}$ Hydrotalcite and the effect of time on the concentrated fulvic acid concentration of $\mathrm{Mg}$
\end{abstract}


/ Al-Fe Hydrotalcite. The characterization results showed the characteristics of the peak and the functional group $\mathrm{Mg} / \mathrm{Al}-\mathrm{Fe}$ Hydrotalcite in X-ray diffractogram and FTIR spectra. The stability of $\mathrm{Mg} / \mathrm{Al}-\mathrm{Fe}$ Hydrotalcite tends to be stable at $\mathrm{pH}$ above 3. Based on FTIR spectra data, Telukpanji fulvic acid has the main functional groups namely - $\mathrm{COOH}$ (aliphatic and aromatic) and phenoh-OH groups. The results of the adsorption pattern of fuvic acid by $\mathrm{Mg} /$ Al-Fe Hydrotalcite are first order reaction kinetics that reach equilibrium with a reaction rate constant (k1) of $24 \times 10^{-4}$ minutes $^{-1}$. The results of post-adsorption characterization showed that fulvic acid entered into the inter-layer of $\mathrm{Mg} / \mathrm{Al}-\mathrm{Fe}$ Hydrotalcite as evidenced by the increase in basal spacing prices in $\mathrm{d} 003$ which is a characteristic of hydrotalcite. The influence of time on the concentrated fulvic acid concentration showed that the fulvic acid could be desorbed from Mg / Al-Fe Hydrotalcite by $82.83 \%$ or $18.52 \mathrm{mg} / \mathrm{L}$ from a total concentration of $22.3556 \mathrm{mg} / \mathrm{L}$.

Keywords: $\mathrm{Mg} / \mathrm{Al}-\mathrm{Fe}$ Hydrotalcite, adsorption, desorption, fulvic acid

\section{PENDAHULUAN}

Lempung merupakan salah satu mineral dengan berbagai aplikasi yang luas seperti keramik, material bangunan, dan juga dalam bidang kimia mempunyai peranan yang penting khususnya sebagai adsorben. Lempung dikelompokkan menjadi dua yaitu lempung kationik dan lempung anionik. lempung anionik mempunyai kemampuan mengikat anion seperti Hydrotalcite. Hydrotalcite dapat digunakan sebagai adsorben senyawa anorganik maupun senyawa organik karenamemiliki kemampuan yang baik untuk memisahkan partikel-partikel koloid dengan ukuran yang sangat halus. Prinsip kerjanya melalui pertukaran ion pada permukaan adsorben maupun pada bidang antar lapisnya dengan senyawa yang ingin diadsorpsi (Xiao, dkk., 2011).

Hydrotalcite merupakan adsorben yang baik dalam perairan sehingga sering digunakan dalam proses pengolahan air bersih, khususnya perairan yang memiliki kandungan senyawa organik tinggi. Air gambut merupakan perairan yang memiliki kadar senyawa organik terlarut sangat tinggi berkisar antara 243-290 $\mathrm{mg} / \mathrm{L}$, sedangkan ambang batas maksimum zat organik dalam air konsumtif adalah 10 $\mathrm{mg} / \mathrm{L}$ (Elfiana dan Zulfikar, 2012).Warna keruh pada air gambut disebabkan oleh senyawa-senyawa humus yang terkandung di dalam air tersebut. Kandungan senyawa humus yang terdapat pada air gambut adalah asam humat, asam fulvat, dan humin.

Asarn fulvat adalah fraksi dari senyawa humat dengan bobot molekul yang kecil, senyawa rantai pendek, berwarna kuning, larut dalam asam maupun basa (Supriyati, 2007). Asam fulvat keberadaannya di perairan dapat menjadi faktor penurunan kualitas air, karena dapat menyebabkan rasa asam yang tidak enak serta warna yang keruh pada perairan.

Usaha untuk meminimalkan kandungan asam fulvat dalam perairan merupakan langkah yang sangat penting untuk dilakukan. Pada penelitian ini, $M g / A l$ Hydrotalcite dimodifikasi dengan penambahan ion $\mathrm{Fe}^{2+}$ dan $\mathrm{Fe}^{3+}$ hasilnya adalah adsorben $\mathrm{Mg} / \mathrm{Al}-\mathrm{Fe}$ Hydrotalcite yang diharapkan memiliki sifat magnet sehingga proses pemisahan adsorben dan adsorbat pasca adsorpsi dapat dilakukan menggunakan medan magnet eksternal.

\section{METODOLOGI PENELITIAN}

\section{Alat dan Bahan}

Alat digunakan adalah Peralatan yang digunakan adalah seperangkat alat gelas, $\mathrm{pH}$ meter (Orion 920A), termometer, hot plate and stirrer, neraca analitik (BP 110 Sartorius), oven listrik (Heraeus UT 6120), lumpang dan mortal agat, sentrifuge, shaker, difraktometer sinar-X (Shimadzu XRD-6000), Flourier 
Transform InfraRed (FTIR),spectrometer $U V$-Visible (Hitachi U2010), dan magnet neodium sebagai separator

Bahan yang digunakan adalah feri klorida heksahidrat $\left(\mathrm{FeCl}_{3} \cdot 6 \mathrm{H}_{2} \mathrm{O}\right)$ buatan E. Merck, fero sulfat heptahidrat $\left(\mathrm{FeSO}_{4} .7 \mathrm{H}_{2} \mathrm{O}\right)$ buatan E Merck, magnesium nitrat heksahidrat $\left(\mathrm{Mg}\left(\mathrm{NO}_{3}\right)_{2} .6 \mathrm{H}_{2} \mathrm{O}\right)$ buatan E. Merck, aluminium nitrat nonahidrat $\left(\mathrm{Al}\left(\mathrm{NO}_{3}\right)_{3} .\left(\mathrm{H}_{2} \mathrm{O}\right)\right.$ buatan E. Merck, natrium hidroksida $(\mathrm{NaOH})$ buatan E. Merck, Asam Nitrat $\left(\mathrm{HNO}_{3}\right)$ buatan E. Merck, akuabides buatan PT. Otsuka Indonesia, kertas saring whatman 42, kertas $\mathrm{pH}$ dan asam fulvat hasil isolasi tanah gambut dari Teluk Panji, Labuhanbatu Selatan, Sumatera Utara.

\section{Prosedur}

\section{a. Isolasi asam fulvat}

Sebanyak $50 \mathrm{~g}$ tanah gambut dimasukkan ke dalam gelas kimia 1 liter. ditambahkan $500 \mathrm{~mL}$ metanol (1:10). Campuran kemudian diaduk dengan menggunakan magnetic stirrer selama 30 menit dan didiamkan selama 24 jam. Supernatan yang terbentuk didekantir, kemudian diasamkan dengan larutan $\mathrm{HNO}_{3}$ $6 \mathrm{~N}$ hingga mencapai $\mathrm{pH}$ 1. Campuran didiamkan kembali selama 20 jam. Supernatan yang terbentuk diambil dan diuapkan pelarutnya menggunakan hot plate pada temperatur $70^{\circ} \mathrm{C}$. Asam fulvat kering hasil ekstraksi dikarakterisasi menggunakan Flourier Transform Infra Red (FTIR).

\section{b. Sintesis $\mathrm{Mg} / \mathrm{Al}$-Fe Hydrotalcite}

Sintesis $\mathrm{Mg} / \mathrm{Al}-\mathrm{Fe} \quad$ Hydrotalcite dilakukan dengan mencampurkan $\mathrm{FeCl}_{3} .6 \mathrm{H}_{2} \mathrm{O}$ dan $\mathrm{FeSO}_{4} .7 \mathrm{H}_{2} \mathrm{O}$ (1:1) ke dalam labu leher tiga yang mengandung larutan $\mathrm{Mg}\left(\mathrm{NO}_{3}\right)_{2} \cdot 6 \mathrm{H}_{2} \mathrm{O}$ dan

$\mathrm{Al}\left(\mathrm{NO}_{3}\right)_{3} .9 \mathrm{H}_{2} \mathrm{O}$ (2:1) kemudian diaduk menggunakanmagnetic stirrer dan dijaga pada suhu $60^{\circ} \mathrm{C}$ dengan interval $\mathrm{pH} 10-13$ kemudian ditambahkan $0,5 \mathrm{M} \mathrm{NaOH}$ tetes demi tetes. Selanjutnya, campuran dihidrotemal pada suhu $110^{\circ} \mathrm{C}$ selama 5 jam. Hasil padatan dicuci dengan akuabides hingga $\mathrm{pH}$ filtrat netral, kemudian endapan dikeringkan dalam oven pada temperatur $110^{\circ} \mathrm{C}$. Padatan kristal yang diperoleh selanjutnya diidentifikasi dan dikarakterisasi menggunakan difraktometer sinar-X (XRD) dan Fourier Transform Infra Red (FTIR).

\section{c. Uji kemagnetan $M g / A l-F e$ Hydrotalcite menggunakan medan magnet luar}

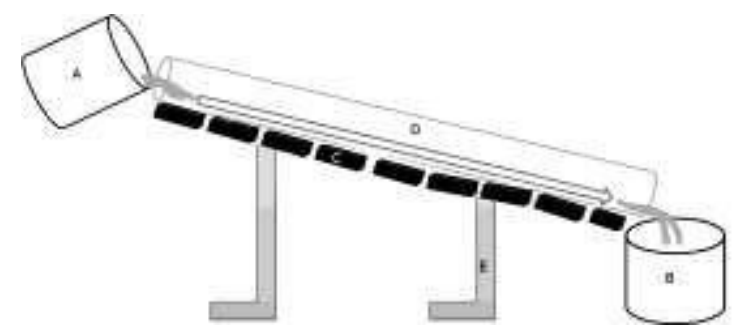

Gambar 1 Mekanisme Pemisahan Adsorben dan Adsorbat Pasca Adsorpsi Menggunakan Medan Magnet Eksternal.

Beberapa g serbuk hasil sintesis dimasukkan kedalam suatu wadah, kemudian ditarik dengan pengaduk magnet dari luar wadah, diamati apakah serbuk tersebut dapat ditarik.Jika padatan $\mathrm{Mg} / \mathrm{AlFe}$ Hydrotalcite dapat tertarik oleh magnet eksternal, maka pemisahan antara adsorben dan adsorbat dapat menggunakan metode sesuai gambar 1 Keterangan gambar:

$$
\begin{aligned}
\mathrm{A} & =\text { Adsorbat }+ \text { adsorben pasca adsorpsi } \\
\mathrm{B} & =\text { Penampung adsorbat } \\
\mathrm{C} & =\text { Magnet } \\
& \text { akan menjerat adsorben } \\
\mathrm{D} & =\text { Jalur pemisahan } \\
\mathrm{E} & =\text { Penopang }
\end{aligned}
$$

\section{d. Uji kestabilan Mg/Al-Fe Hydrotalcite terhadap pH}

Pelarut akuabides dibuat sederet dengan variasi $\mathrm{pH} \mathrm{1,} \mathrm{3,} \mathrm{5,} \mathrm{7,} \mathrm{9,} 11$ dan 13 . Pada masing-masing pelarut tersebut 0,2 $\mathrm{g} M g / A l-F e$ Hydrotalcite ditambahkan, kemudian dishaker selama 200 menit. Selanjutnya, endapan disaring dan dikeringkan dalam oven pada temperature $100{ }^{\circ}$ C.Endapan kering ditimbang dan dibuat grafik $\mathrm{pH}$ versus persen berat $\mathrm{Mg} / \mathrm{Al}-\mathrm{Fe}$ Hydrotalcite yang tersisa. 


\section{Kinetika adsorpsi asam fulvat pada Mg/Al -FeHydrotalcite}

Sebanyak $0,05 \quad \mathrm{~g} \quad \mathrm{Mg} / \mathrm{Al}-\mathrm{Fe}$ Hydrotalcite diinteraksikan dengan $20 \mathrm{~mL}$ asam fulvat dengan konsentrasi $50 \mathrm{mg} / \mathrm{L}$ dalam Erlenmeyer $50 \mathrm{~mL}$ pada $\mathrm{pH} 5$. Waktu interaksi ditentukan pada waktu 5 , 20, 30, 120, 180, 360, dan 380 menit. Campuran digojok menggunakanshaker waterbath kemudian pemisahan antara adsorben dan adsorbat dilakukan dengan cara menjerat adsorben menggunakan medan magnet eksternal. Selanjutnya masing-masing filtrat diukur absorbansinya menggunakan spektrofotometer $U V$ Visible.

\section{Kajian desorpsi asam fulvat dari Mg/Al-FeHydrotalcite}

\section{a. Karakterisasi $\mathbf{M g} / \mathrm{Al}$-FeHydrotalcite} pasca adsorpsi

$$
\text { Sebanyak } \quad 0,7 \mathrm{~g} \quad \mathrm{Mg} / \mathrm{Al} \text { - }
$$

FeHydrotalcitediinteraksikan dengan 50 $\mathrm{mg} / \mathrm{L}$ larutan asam fulvat pada $\mathrm{pH} 5$ selama 6 jam. Selanjutnya, adsorbat dan adsorben dipisahkan dengan cara menjerat adsorben menggunakan medan magnet eksternal. Endapan adsorben pasca adsorpsi dikeringkan pada temperatur $70^{\circ} \mathrm{C}$ selama 2 jam lalu dikarakterisasi menggunakan Fourier Transform InfraRed (FTIR) dan difraktometer sinar-X (XRD).

\section{HASIL DAN PEMBAHASAN}

Interpretasi spektra inframerah menunjukkan bahwa asam fulvat hasil isolasi didominasi oleh gugus aktif hidroksil $(-\mathrm{OH})$ fenolat maupun alkoholat dan karboksilat $(-\mathrm{COOH})$. Gugus fungsi $\mathrm{OH}$ teramati dengan puncak serapan yang muncul pada bilangan gelombang sekitar $3425,58 \mathrm{~cm}^{-1}$, sedangkan gugus $-\mathrm{COOH}$ memiliki serapan pada bilangan gelombang $1381,03 \mathrm{~cm}^{-1}$ diperkuat dengan munculnya puncak serapan pada bilangan gelombang $1712,79 \mathrm{~cm}^{-1}$ yang merupakan serapan dari b. Desorpsi asam fulvat dari $M g / A l$ FeHydrotalcite Sebanyak 0.1g $\mathrm{Mg} / \mathrm{Al}$ FeHydrotalcitefulvat dilarutkan dalam 15 $\mathrm{mL} \quad \mathrm{NaOH} \quad 0,5 \quad \mathrm{M}$ dan digojok menggunakan shaker waterbath dengan variasi waktu $5,15,30$,

60, 120, dan 240 menit. $M g / A l$ -

FeHydrotalcitepasca desorpsi dipisahkan dengan filtratnya menggunakan medan magnet eksternal. Masing-masing filtrat diukur absorbansinya menggunakan gelombang $1712,79 \mathrm{~cm}^{-1}$ yang merupakan serapan dari gugus karbonil $(\mathrm{C}=\mathrm{O})$.

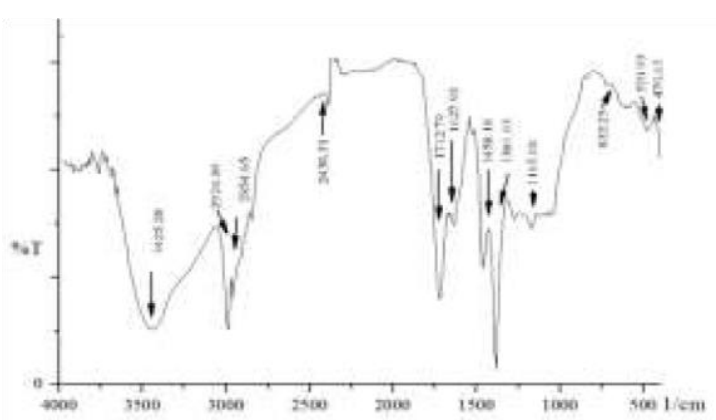

Gambar2. Spektra FTIR asam fulvat hasil isolasi

Untuk dapat membuktikan sifat magnetik dari material maka perlu dilakukan pengujian dengan caramenarik padatan $\mathrm{Mg} / \mathrm{Al}-\mathrm{Fe} \quad$ Hydrotalcite menggunakan medan magnet luar.Hasil pengujian menunjukkan bahwa padatan Mg/Al-Fe Hydrotalcite bersifat magnetik sehingga dapat tertarik oleh medan magnet luar. Saat medan magnet luar ditempelkan

gugus karbonil $(\mathrm{C}=\mathrm{O})$.spektra FTIR asam fulvat disajikan padaGambar 2 .

Interpretasi spektra inframerah menunjukkan bahwa asam fulvat hasil isolasi didominasi oleh gugus aktif hidroksil $(-\mathrm{OH})$ fenolat maupun alkoholat dan karboksilat $(-\mathrm{COOH})$. Gugus fungsi $\mathrm{OH}$ teramati dengan puncak serapan yang muncul pada bilangan gelombang sekitar $3425,58 \mathrm{~cm}^{-1}$, sedangkan gugus $-\mathrm{COOH}$ memiliki serapan pada bilangan gelombang $1381,03 \mathrm{~cm}^{-1}$ diperkuat dengan munculnya puncak serapan pada bilangan $F e$ Hydrotalcite yang mula-mula diam akan bergerak kearah magnet.Magnetit menunjukkan sifat listrik dan magnet yang 
didasarkan pada transfer elektron di antara ion $\mathrm{Fe}^{2+}$ dan ion $\mathrm{Fe}^{3+}$ pada sisi oktahedral (Yan, dkk., 2009). Magnetit dapat tertarik medan magnet dengan kuat namun sifat kemagnetannya akan hilang setelah medan magnet dihilangkan. Berdasarkan sifat magnet yang dimiliki material hasil sintesis, pemisahan material adsorben dari adsorbat pasca adsorpsi dapat dilakukan menggunakan medan magnet eksternal melalui jalur pemisahan pada gambar.1(Chang, dkk., 2011).

\section{Kestabilan Mg/Al-Fe Hydrotalcite terhadap pH}

Uji kestabilan $\mathrm{Mg} / \mathrm{Al}$-Fe Hydrotalcite dilakukan untuk mengetahui pengaruh $\mathrm{pH}$ terhadap stabilitas material, untuk mengetahuinya maka dilakukan pengujian dengan menambahkan 0,2 g Mg/Al-Fe Hydrotalcitekedalam akuades denganvariasi $\mathrm{pH}$ 1, 3, 5, 7, 9, 11, dan 13 . Selanjutnya, larutan diaduk menggunakan shaker waterbathselama 200 menit, kemudian endapan disaring dan dikeringkan dalam oven.Setelah kering endapan ditimbang kembali.dibuat grafik persentase sisa $\mathrm{Mg} / \mathrm{Al}-\mathrm{Fe}$ Hydrotalcite lawan pH. Grafik kestabilan Mg/Al-Fe Hydrotalcite pada berbagai $\mathrm{pH}$ ditunjukkan pada Gambar 3.

Berdasarkan grafik kestabilan material sintesis, padatan $\mathrm{Mg} / \mathrm{Al}-\mathrm{Fe}$ Hydrotalciterelatif stabil pada $\mathrm{pH}$ di atas 3. $\mathrm{Mg} / \mathrm{Al}$ Hydrotalcite terbentuk pada interval pH 9-13 (Karmanto, 2006). Akan tetapi, pada gambar 3 memperlihatkan bahwa menyebabkan kompetisi antara anion pada antar lapis $\mathrm{Mg} / \mathrm{Al}-\mathrm{Fe}$ Hydrotalcite dengan anion $\mathrm{OH}^{-}$dalam larutan (Chang, dkk., 2011).Ion $\mathrm{OH}^{-}$terbentuk akibat penambahan $\mathrm{NaOH}$ yang semakin banyak pada $\mathrm{Mg} / \mathrm{Al}-\mathrm{Fe}$ Hydrotalcite. Hal yang sama terjadi pada rentang $\mathrm{pH}$ di bawah 3 yang kurang stabil. Pada $\mathrm{pH}$ di bawah 3 kandungan ion $\mathrm{H}^{+}$cukup besar sehingga anion-anion dalam bidang antar lapis seperti ion nitrat dan hidroksida lebih banyak yang berikatan dengan $\mathrm{H}^{+}$ membentuk asam nitrat dan molekul air. Akibat berkurangnya anionanion tersebut menyebabkan lembar bidang lapis semakin bermuatan positif sehingga $\mathrm{Mg} / \mathrm{Al}-\mathrm{Fe}$ Hydrotalcite menjadi tidak stabil.

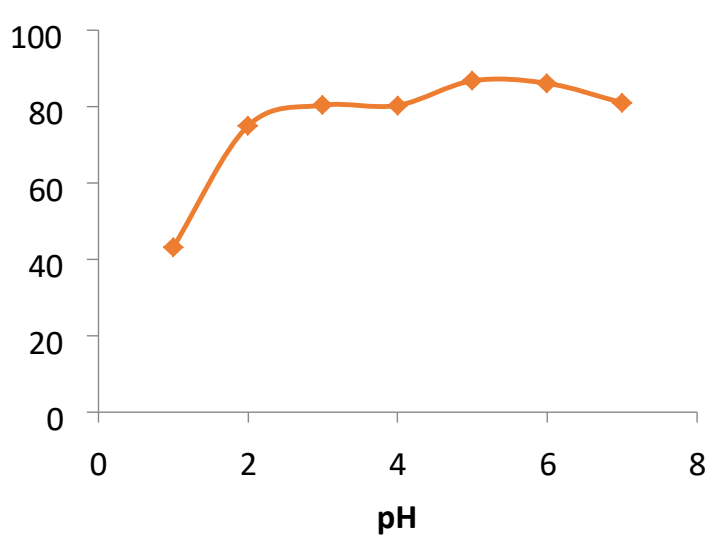

Gambar 3. Grafik kestabilan $M g / A l-F e$

pada $\mathrm{pH} 13$ kestabilan Mg/Al-Fe Hydrotalcite mengalami penurunan.Hal ini disebabkan karena pada $\mathrm{pH}$ tinggi semakin banyak anion $\mathrm{OH}^{-}$dalam larutan yang akan

Hasil pengujian kestabilan $\mathrm{Mg} / \mathrm{Al}-\mathrm{Fe}$ Hydrotalciteterhadap $\mathrm{pH}$ relatif stabil pada $\mathrm{pH}$ di atas 3 disebabkan karena pada $\mathrm{pH}$ di atas 3 jumlah ion $\mathrm{H}^{+}$dalam larutan kecil, sehingga tidak banyak anion-anion pada daerah antar lapis ataupun ion hidroksida pada lembar bidang lapis $M g / A l-F e$ Hydrotalcite yang mengikat $\mathrm{H}^{+}$dalam larutan.Data kestabilan material tersebut dapat digunakan sebagai dasar bahwa $\mathrm{Mg} / \mathrm{Al}-\mathrm{Fe}$ Hydrotalcite hasil sintesis, dapat diaplikasikan langsung pada perairan gambut yang pada umumnya memiliki rentang $\mathrm{pH}$ 3-5 (Elfiana dan Zulfikar, 2012). 


\section{B. Kinetika Adsorpsi Asam Fulvat oleh Mg/Al-Fe Hydrotalcite}

Kinetika adsorpsi menyatakan adanya proses penyerapan suatu zat oleh adsorben sebagai fungsi waktu (Atkins, 1999), sehingga kinetika adsorpsi asam fulvat pada $\mathrm{Mg} / \mathrm{Al}-\mathrm{Fe}$ Hydrotalcite dapat dipelajari dengan membuat pola adsorpsi antara persentase asam fulvat teradsorpsi lawan $\mathrm{t}$ (menit). Grafik persentase asam fulvat teradsorp lawan $\mathrm{t}$ (menit) disajikan pada Gambar 4.

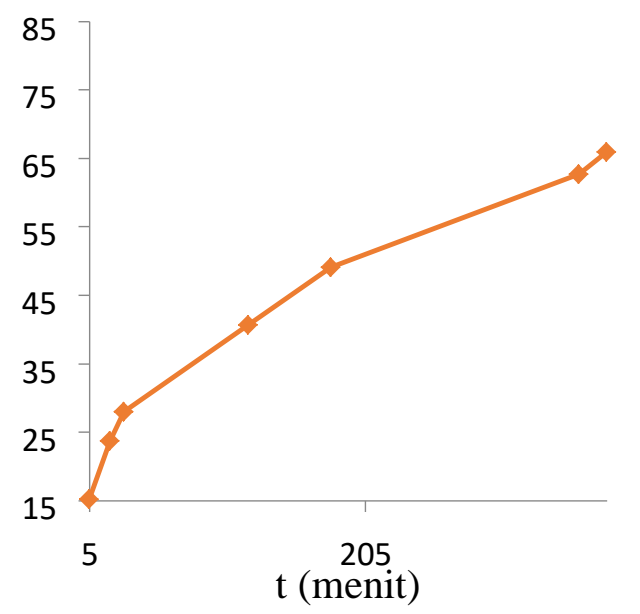

Gambar 4 Grafik persen asam fulvat teradsorp pada $\mathrm{Mg} / \mathrm{Al}$-Fe Hydrotalcite

Gambar 4 menunjukkan bahwa persen asam fulvat teradsorp berbanding lurus dengan waktu yang artinya semakin lama waktu interaksi semakin meningkat persen asam fulvat teradsorp.Terlihat bahwa pada interval waktu 0-30 menit terjadi kenaikan jumlah asam fulvat terdesorpsi dari $\mathrm{Mg} / \mathrm{Al}$ $\mathrm{Fe}$ Hydrotalcite hingga akhirnya tidak terjadi lagi perubahan yang signifikan pada menit ke120 hingga akhir interaksi, hal tersebut karena permukaan maupun bagian antar lapis $\mathrm{Mg} / \mathrm{Al}-\mathrm{Fe}$ Hydrotalcite mulai penuh terisi oleh asam fulvat teradsorp.

Selanjutnya, ditentukan orde reaksi adsorpsi asam fulvat pada $\mathrm{Mg} / \mathrm{Al}-\mathrm{Fe}$ Hydrotalcite.Dari hasil persamaan kinetika reaksi adsorpsi asam fulvat pada $\mathrm{Mg} / \mathrm{Al}-\mathrm{Fe}$ Hydrotalcite menunjukkan bahwa reaksi yang terjadi adalah orde satu.Hal ini dilihat dari harga nilai $\mathrm{R}^{2}$ pada orde satu merupakan yang terbesar dibandingkan dengan orde dua maupun tiga.Berikut disajikan perhitungan orde reaksi pada Table.1.

Tabel.1. Perbandingan nilai koefisien korelasi orde satu, orde dua dan orde tiga.

\begin{tabular}{cccc}
\hline Orde & Pers. Reaksi & $\begin{array}{c}\text { Koef. } \\
\text { Korela } \\
\text { si }\left(\mathrm{R}^{2}\right)\end{array}$ & $\begin{array}{c}\text { Koef. } \\
\text { Laju } \\
\text { Reaksi } \\
(\mathrm{k})\end{array}$ \\
\hline Orde 1 & $\begin{array}{l}(\ln [\mathrm{A}]=-\mathrm{kt}+ \\
\ln [\mathrm{A}]_{0}\end{array}$ & 0,9768 & $\begin{array}{c}0,0024 \\
\mathrm{~min}^{-1}\end{array}$ \\
Orde 2 & $\begin{array}{l}(1 /[\mathrm{A}]=\mathrm{kt}+ \\
1 /[\mathrm{A}]_{0}\end{array}$ & 0,9558 & $\begin{array}{c}11,160 \\
\mathrm{~min}^{-1}\end{array}$ \\
Orde 3 & $\begin{array}{l}1 / 2[\mathrm{~A}]^{2}=\mathrm{kt}+ \\
\left.1 / 2[\mathrm{~A}]_{0}^{2}\right)\end{array}$ & 0,9003 & $\begin{array}{c}198800 \\
\mathrm{~min}^{-1}\end{array}$ \\
\hline
\end{tabular}

Tabel 1 menunjukkan bahwa kinetika adsorpsi $\mathrm{Mg} / \mathrm{Al}$-Fe Hydrotalcite mengikuti persamaan reaksi orde satu dengan harga $\mathrm{R}^{2}$ sebesar 0,9768. Oleh karena itu, parameter kinetika $\left(\mathrm{k}_{1}\right)$ untuk adsorpsi asam fulvat pada $\mathrm{Mg} / \mathrm{Al}-\mathrm{Fe}$ Hydrotalcite ditentukan berdasarkan persamaan (12) dari penurunan rumusan kinetika orde satu yang mencapai kesetimbangan (Santosa dan Muzakky. 2002). Kinetika yang digunakan ditentukan dari persamaan (12) dengan membuat kurva $\ln \frac{\frac{C A 0}{C A}}{C A}$ lawan $\mathrm{t} / \mathrm{C}_{\mathrm{A}}$ akan diperoleh harga $\mathrm{K}$ dan $\mathrm{k}_{1}$ dari intersep dan slop. Selain itu dibuat juga pembanding persamaan reaksi orde satu umum, yakni grafik hubungan antara $\ln \left(\mathrm{C}_{\mathrm{A}} / \mathrm{C}_{\mathrm{A} 0}\right)$ lawan $\mathrm{t}$. Apabila grafik yang didapat dari kinetika Santosa dan Muzakky menghasilkan garis yang lebih linear, maka dapat diartikan bahwa pola interaksi asam fulvat oleh $\mathrm{Mg} / \mathrm{Al}-\mathrm{Fe}$ Hydrotalcite melibatkan proses adsorpsi. 
Tabel.2. Perbandingan nilai koefisien korelasi dari persamaan antara kinetika orde satu Santosa dan Muzakky dan orde satu umum untuk adsorpsi asam fulvat pada Mg/Al-Fe Hydrotalcite.

\begin{tabular}{|c|c|c|c|}
\hline Orde Reaksi & Pers. Reaksi & $\begin{array}{c}\text { Koef. } \\
\text { Korelasi } \\
\left(\mathrm{R}^{2}\right) \\
\end{array}$ & $\begin{array}{l}\text { Koef.Laju } \\
\text { Reaksi (k) }\end{array}$ \\
\hline $\begin{array}{c}\text { Orde } 1 \\
\text { (Santosa dan } \\
\text { Muzakky) }\end{array}$ & {$\left[\frac{\ln \frac{E C_{A_{0}}}{E C_{A}} E=}{C_{A}} E=\right.$} & 0,9868 & 72,53 menit $^{-1}$ \\
\hline Orde 1 umum & 0,9768 & $\begin{array}{r}(\ln ([ \\
0,0024 \text { men } \\
\end{array}$ & \\
\hline
\end{tabular}

Grafik kinetika adsorpsi orde satu umum dan orde satu Santosa dan Muzakky disajikan pada Gambar 5 dan 6.

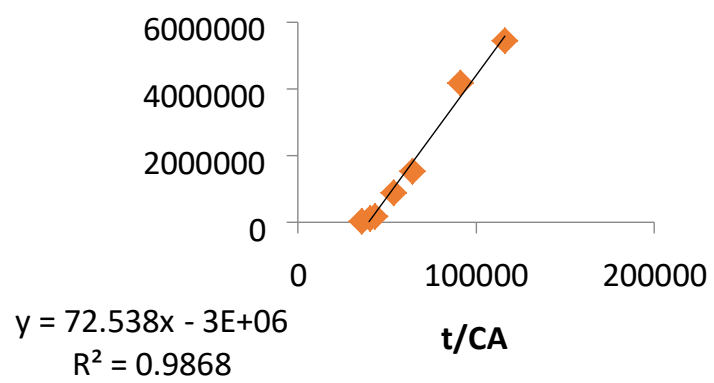

Gambar 5.Grafik kinetika adsorpsi orde satu (Santosa dan Muzakky) untuk adsorpsi asam fulvat pada $\mathrm{Mg} / \mathrm{Al}-\mathrm{Fe}$

Hydrotalcite.

Grafik hubungan $\ln \left(\mathrm{C}_{\mathrm{A} 0} / \mathrm{C}_{\mathrm{A}}\right) / \mathrm{C}_{\mathrm{A}}$ lawan $\mathrm{t} / \mathrm{C}_{\mathrm{A}}$ pada gambar 5 adalah linier, dengan nilai $R^{2}=0,9868$, harga konstanta laju raksi $\left(\mathrm{k}_{1}\right)=72,53$ menit ${ }^{-1}$ dan konstanta kesetimbangan $(\mathrm{K})$ bernilai $3 \mathrm{x}$ $10^{6}$. Karena $\mathrm{K}$ merupakan $\mathrm{k}_{1} / \mathrm{k}_{-1}$, maka harga konstanta laju desorpsi $\mathrm{k}_{-1 \mathrm{~A}}=25,18 \mathrm{x}$ $10^{-5}$ menit $^{1}$. Hal ini sesuai dengan asumsi dari rumusan kinetika adsorpsi (Santosa dan Muzakky. 2002) bahwa adsorpsi asam fulvat padasuatu kation merupakan adsorpsi orde satu yang mencapai kesetimbangan. Sebagai perbandingan terhadap data kinetika adsorpsi yang diperoleh dari rumusan kinetikaadsorpsi orde satu yang mencapai kesetimbangan (Santosa dan Muzakky. 2002) maka telah dibuat juga grafik kinetika orde satu umum berupa grafik $\ln \left(\mathrm{C}_{\mathrm{A}} / \mathrm{C}_{\mathrm{A} 0}\right)$ lawan $\mathrm{t}$ yang disajikan pada Gambar 6.
Apabila adsorpsi asam fulvat oleh $\mathrm{Mg} / \mathrm{Al}$-FeHydrotalciteadalah orde satu maka plot antara $\ln \left(\mathrm{C}_{\mathrm{A}} / \mathrm{C}_{\mathrm{A} 0}\right)$ lawan $\mathrm{t}$ haruslah menghasilkan hubungan yang linier (Atkins, 1999). Gambar 6 menunjukkan bahwa grafik $\ln \left(\mathrm{C}_{\mathrm{A}} / \mathrm{C}_{\mathrm{A} 0}\right)$ lawan $\mathrm{t}$ memberikan hubungan yang linear. Harga k 1 untuk reaksi orde satu adalah negatif dari nilai slope. Perhitungan slope pada plot grafik $\ln \left(\mathrm{C} \quad \mathrm{A}_{\mathrm{A}} / \mathrm{C}_{\mathrm{A} 0}\right)$ vs $\mathrm{t}$ menghasilkan harga $\mathrm{k}_{1}$ sebesar $24 \times 10^{-4}$ dan $\mathrm{R}^{2}$ sebesar 0,9768, meskipun harga konstanta laju reaksi tidak menunjukkan hasil yang sama dengan konstanta laju reaksi yang didapat dari kinetika orde satu (Santosa dan Muzakky. 2002). Maka dapat dikatakan bahwa kinetika $\mathrm{pH} 5$ merupakan kinetika adsorpsi orde satu dengan orde satu yang mencapai kesetimbangan.

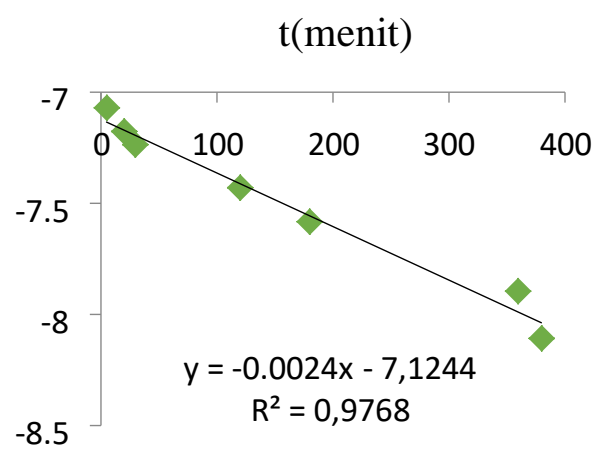

Gambar 6 Grafik kinetika adsorpsi orde

satu umum untuk adsorpsi asam fulvat pada Mg/Al-Fe Hydrotalcite.

\section{Kajian Desorpsi Asam Fulvat dari Mg/Al-Fe Hydrotalcite}

\section{Karakteristik pasca adsorpsi}

Karakterisasi material sintesis pasca adsorpsi menggunakan FTIRdan XRD dilakukan untuk mengetahui apakah terjadi proses adsorpsi asam fulvat dengan mengamati perubahan pita serapan anionanion pada bagian antar lapis $\mathrm{Mg} / \mathrm{Al}$ $\mathrm{Fe}$ Hydrotalcite serta pergeseran puncak pada spektra XRD. Data FTIR dan XRD pasca adsorpsi juga dapat dijadikan bukti bahwa proses adsorpsi asam fulvat pada $\mathrm{Mg} / \mathrm{Al}-\mathrm{Fe}$ Hydrotalcite terjadi secara monolayer. Perubahan spektra infra merah $\mathrm{Mg} / \mathrm{Al}-\mathrm{Fe}$ Hydrotalcite setelah proses adsorpsi ditampilkan pada gambar 7 . 


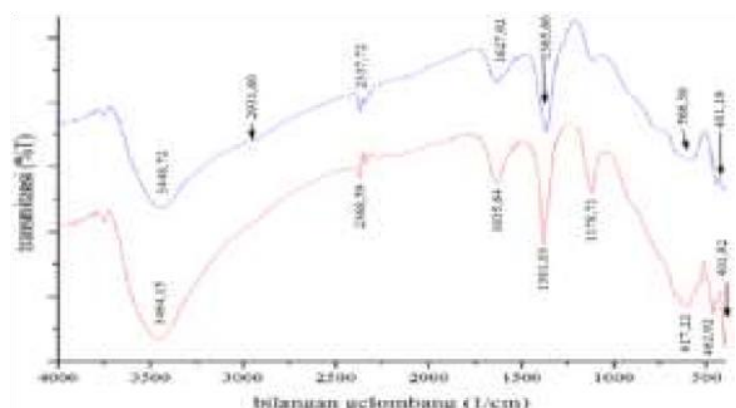

Gambar 7 Spektra infra merah (A) $M g / A l$ $\mathrm{Fe}$ Hydrotalcite-Fulvat dan biru (B) Mg/AlFe Hydrotalcite

Gambar 7 menunjukkan bahwa

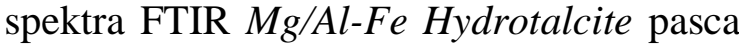
mengadsorpsi asam fulvat mengalami penurunan dan pergeseran intensitas pita serapan pada daerah $3464,15 \mathrm{~cm}^{-1}$ menjadi $3448,72 \mathrm{~cm}^{-1}$ yang menunjukkan adanya pengurangan pada vibrasi stretching gugus hidroksi dari molekul $\mathrm{H}_{2} \mathrm{O}$ yang terdapat pada daerah antar lapisnya karena adanya interaksi dengan gugus aktif asam fulvat. Hal ini juga diperkuat dengan bergesernya pita serapan pada bilangan gelombang $1635,64 \mathrm{~cm}^{-1} \mathrm{ke}$ bilangan gelombang $1627,92 \mathrm{~cm}^{-1}$ yang merupakan vibrasi bending gugus hidroksi dari molekul $\mathrm{H}_{2} \mathrm{O}$. Terdapat pengurangan pita serapan ion nitrat $\left(\mathrm{NO}_{3}{ }^{-}\right)$pada daerah serapan 1381,05 $\mathrm{cm}^{-1}$ akibat substitusi anion pada daerah antar lapis dengan asam fulvat. Selain itu muncul juga pita serapan baru pada bilangan gelombang 2931,60 $\mathrm{cm}^{-1}$ yang merupakan karakteristik dari $\mathrm{C}-\mathrm{H}$ alifatik yang berasal dari struktur asam fulvat.

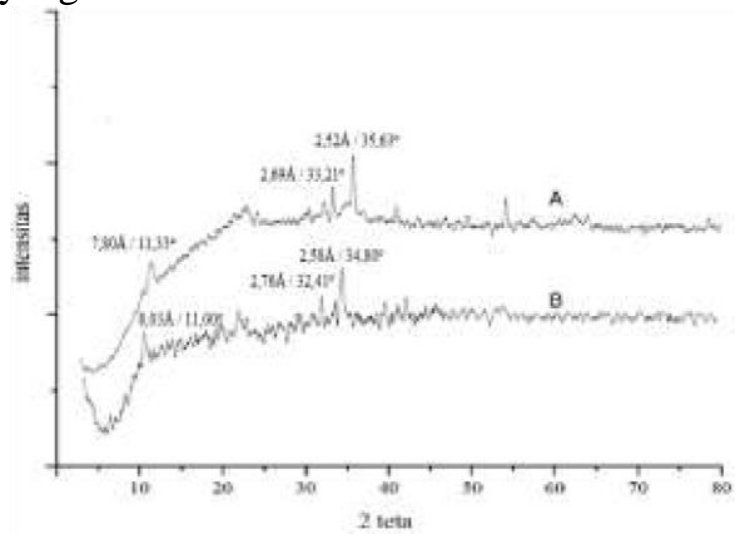

Gambar 8.Difraktogram (A) $\mathrm{Mg} / \mathrm{Al}-\mathrm{Fe}$ Hydrotalcite (B) Mg/Al-Fe HydrotalciteFulvat

Interpretasi dengan difraktometer sinar-X dimaksudkan untuk mengetahui apakah terjadi adsorpsi asam fulvat pada situs aktif adsorben.Perubahan intensitas yang terjadi yang menunjukkan adanya perubahan susunan ion dalam daerah antar lapis $\mathrm{Mg} / \mathrm{Al}-\mathrm{Fe}$ Hydrotalcite. Difraktogram Mg/Al-Fe Hydrotalcite sebelum dan setelah mengadsorpsi asam fulvat disajikan pada Gambar.8.

Harga $d$ kedua spektra pada Gambar. 8 memperlihatkan bahwa asam fulvat teradsorp pada antar lapis $\mathrm{Mg} / \mathrm{Al}-\mathrm{Fe}$ Hydrotalcite, ditunjukkan dengan adanya perubahan nilai basal spacing $(d)$ setelah adsorpsi.Nilai basal spacing dari $\mathrm{Mg} / \mathrm{Al}-\mathrm{Fe}$ Hydrotalcite pada $\mathrm{d}_{003}$ yang merupakan karakteristik untuk senyawa hydrotalcite mengalami kenaikan.Sebelum adsorpsi basal spacing $\mathrm{d}_{003}$ memiliki nilai $d$ sebesar $7,80 \AA$ kemudian setelah adsorpsi mengalami kenaikan menjadi 8,03A.Pergeseran basal spacing ini disebabkan karena masuknya asam fulvat ke dalam antar lapis $\mathrm{Mg} / \mathrm{Al}-\mathrm{Fe}$ Hydrotalcite yang menggantikan anion nitrat.

Data ini diperkuat dengan hasil FTIR pada Gambar 7 yang menunjukkan adanya penurunan puncak serapan pada bilangan gelombang $1381,03 \mathrm{~cm}^{-1}$ yang merupakan karakteristik dari anion nitrat. Asam fulvat diasumsikan memiliki ukuran lebih besar dibandingkan dengan anion nitrat sehingga dapat menyebabkan kenaikan basal spacing. Pertukaran anion berdimensi kecil oleh anion yang lebih besar akan menyebabkan kenaikan basal spacing ke arah yang lebih besar (Perez dkk., 2006).

Dari kedua data karakterisasi menggunakan FTIR dan XRD dapat disimpulkan bahwa terjadi pergantian anion nitrat yang ada pada antar lapis $\mathrm{Mg} / \mathrm{Al}-\mathrm{Fe}$ Hydrotalcite dengan asam fulvat yang membuktikan bahwa interaksi asam fulvat dengan $\mathrm{Mg} / \mathrm{Al}$ $\mathrm{Fe}$ Hydrotalcite terjadi secara monolayer.

Tabel 3 Harga $d(\AA)$ / 20Mg/Al-Fe Hydrotalcite Sebelum dan Setelah

Adsorpsi Asam Fulvat $d(\AA) / 2 \theta$

$\begin{array}{cc}\text { Sebelum adsorpsi } & \text { Setelah adsorpsi } \\ 7,80 \AA / 11,33^{\circ} & 8,03 \AA / 11,00^{\circ}\end{array}$

$7,80 \AA / 11,33^{\circ} \quad 8,03 \AA / 11,00^{\circ}$ 


\begin{tabular}{ll}
$3,82 \AA / 23,22^{\circ}$ & $3,97 \AA / 22,39^{\circ}$ \\
$2,69 \AA / 33,21^{\circ}$ & $2,76 \AA / 32,41^{\circ}$ \\
$2,52 \AA / 35,63^{\circ}$ & $2,58 \AA / 34,80^{\circ}$ \\
\hline
\end{tabular}

2. Desorpsi asam fulvat dari $\mathrm{Mg} / \mathrm{Al}-\mathrm{Fe}$ Hydrotalcite

Kajian desorpsi pada penelitian ini bertujuan untuk mengetahui kemudahan melepas asam fulvat yang telah teradsorpsi oleh adsorben $\mathrm{Mg} / \mathrm{Al}-\mathrm{Fe}$

Hydrotalcite.Kajian desorpsi terhadap $\mathrm{Mg} / \mathrm{Al}-\mathrm{Fe} \quad$ Hydrotalcite dilakukan menggunakan metode Batch yaitu dengan mempertukarkan asam fulvat dengan anionanion lain yang sesuai. Anion yang digunakan untuk desorpsi asam fulvat adalah anion $\mathrm{OH}^{-}$dari larutan $\mathrm{NaOH}$ 0,5 M. Pemilihan anion $\mathrm{OH}^{-}$didasarkan atas asumsi bahwa permukaan hydrotalcite memiliki sisi aktif bermuatan positif yang bersifat sebagai asam keras. Berdasarkan prinsip HSAB (Hard Soft Acid and Base), suatu asam keras akan lebih suka berikatan dengan suatu basa keras, ion $\mathrm{OH}^{-}$ merupakan salah satu jenis dari basa keras sehingga diharapkan penggantian asam fulvat dengan $\mathrm{OH}^{-}$akan lebih mudah dilakukan.

Percobaan desorpsi ini dilakukan dengan memvariasi waktu desorpsi dari 5120 menit.Variasi waktu dilakukan untuk mengetahui waktu optimum desorpsi asam fulvat dari permukaan $\mathrm{Mg} / \mathrm{Al}-\mathrm{Fe}$ Hydrotalcite.Hasil pengukuran menunjukkan bahwa pada interval waktu 5120 menit terjadi kenaikan jumlah asam fulvat terdesorpsi dari $\mathrm{Mg} / \mathrm{Al}-\mathrm{Fe}$

Hydrotalcite hingga akhirnya tidak terjadi lagi perubahan yang signifikan pada menit ke-240. Hal itu disebabkan karena sebagian adsorbat asam fulvat masih teradsorb pada adsorben sehingga proses desorpsi tidak mencapai $100 \%$ dan relative konstan pada interval waktu 120-240 menit.Hubungan \%terdesorpsi asam fulvat dengan waktu desorpsi disajikan pada Gambar 9.

Fulvat dengan Waktu Desorpsi pada Mg/Al-Fe Hydrotalcite

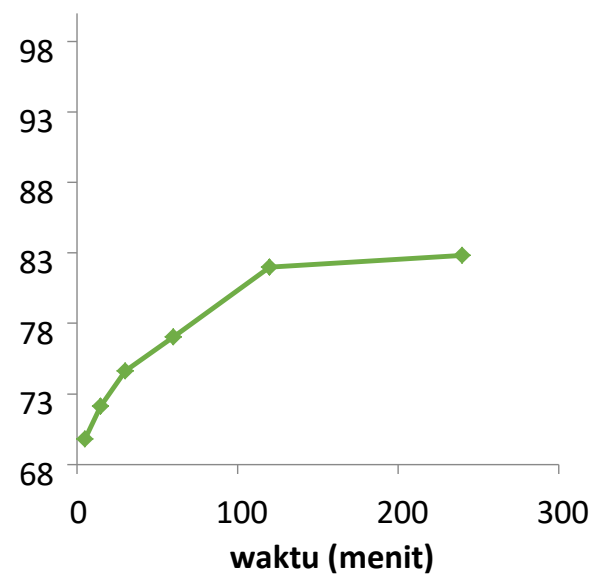

Gambar9 Hubungan \%terdesorpsi Asam

\section{KESIMPULAN}

Berdasarkan hasil penelitian dan pembahasan yang dilakukan, maka dapat ditarik kesimpulan sebagai beriku:

1. Hasil XRD padatan $M g / A l-F e$ Hydrotalcite menunjukkan puncakpuncak utama yang khas pada sudut difraksi $11,33^{\circ}, 33,21^{\circ}$ dan 35,63․ Sedangkan spektra FTIR menunjukkan adanya ikatan $\mathrm{Mg}-\mathrm{OH}$, $\mathrm{Al}-\mathrm{OH}$ dan $\mathrm{FeOH}$ serta adanya anion nitrat yang mengisi antar lapisnya.

2. Hasil FTIR asam fulvat menunjukkan bahwa asam fulvat hasil isolasi memiliki gugus aktif $-\mathrm{COOH}$ dan $-\mathrm{OH}$ fenolat maupun alkoholat.

3. Adsorpsi asam fulvat oleh $\mathrm{Mg} / \mathrm{Al}-\mathrm{Fe}$ Hydrotalcite merupakan kinetika reaksi orde satu yang mencapai kesetimbangan dengan konstanta laju reaksi $\left(\mathrm{k}_{1}\right)$ sebesar $2,4 \times 10^{-3}$ menit $^{-1}$. Desorpsi asam fulvat dari $\mathrm{Mg} / \mathrm{Al}-\mathrm{Fe}$ Hydrotalcite yang mulai konstan pada menit ke-240 dan memiliki nilai persen desorpsi sebesar $82,23 \%$ atau 18,52 $\mathrm{mg} / \mathrm{L}$ dari konsentrasi total sebesar $22,35 \mathrm{mg} / \mathrm{L}$

4. Asam fulvat teradsorpsi ke dalam antar lapis hydrotalcite ditunjukkan dengan peningkatan harga basal spacing d003yang merupakan karakteristik dari hydrotalcite.

5. Hasil pengujian magnet eksternal menunjukkan hasil bahwa material $\mathrm{Mg} / \mathrm{Al}-\mathrm{Fe}$ Hydrotalcite hasil sintesis memiliki sifat magnetik, sehingga 
pemisahan antara adsorben dan larutan adsorbat pasca adsorpsi dapat dilakukan menggunakan bantuan medan magnet eksternal.

\section{DAFTAR PUSTAKA}

Atkins, P.W. 1999. Kimia Fisika, Edisi ke2. Erlangga. Jakarta.

Chang, Qing., Zhu, Lihua., Luo, Zhihong., Lei, Min., Zhang, Suicheng., dan Tang, Heqing. 2011. Sono-Assisted Preparation of Magnetic MagnesiumAluminum Layered Double Hydroxides and Their Application for Removing Fluoride. Ultrasonics Sonochemistry. Vol 18. 553-561.

Elfiana dan Zulfikar. 2012. Penurunan Konsentrasi Organik Air Gambut secara AOP (Advanced Oxidation Processes) dengan Fotokimia Sinar Uv. Politeknik Negeri Lhokseumawe. Lhokseumawe.

Karmanto. 2006. Sintesis

$\mathrm{Mg} / \mathrm{Al}$ Hydrotalcite Sebagai Adsorben Asam Humat. Skripsi. FMIPA UGM Yogyakarta.

Perez, M.R., Pavlovic, L., Barriga, C., dan Cornejo, J. 2006. Uptake of $\mathrm{Cu} 2+$, $\mathrm{Cd} 2+$, and $\mathrm{Pb} 2+$ on $\mathrm{Zn}-\mathrm{Al}$ Layered Double Hydroxide Intercalated with EDTA. App. Clay Science. Vol 32. 245-251

Santosa dan Muzakky. 2002. Kinetika Adsorpsi Logam Berat (Krom, Tembaga, dan Uranium) Oleh Senyawa Humat Dalam Tanah Gambut. Laporan Penelitian, penelitian dasar. Lembaga Penelitian UGM. Yogyakarta.

Supriyati, 2007. Pengaruh Prebiotik Asam Fulvat Terhadap Kandungan Kolesterol Dalam Daging Ayam. Balai penelitian ternak. Bogor.

Xiao, Ying Kai., Liu, Yu Ping., Xu, Wan Bang., Liang, Mei Fang., Cheng, Jian., Wan, Jian Ping., dan Chen, Ling Zhu. 2011. Synthesis and structural analysis of a regular $\mathrm{CuMg}-\mathrm{Al}$ hydrotalcite-like compound. Turkish Journal of Chemistry. Vol 35. 881-891.

Yan, Hao., Zhang, Jiancheng., You, Chenxia., Song, Zhenwei., Yu, Benwei., dan Shen, Yue. 2009. Influences of Different Synthesis Conditions on Properties of $\mathrm{Fe} 3 \mathrm{O} 4$ Nanoparticles. Materials Chemistry and Physics. Vol 113. 46-52. 